\title{
Corrosion problems and solutions in oil, gas, refining and petrochemical industry
}

\section{Korozní problémy při zpracování plynu a ropy}

Groysman A.

Technion (Israeli Institute of Technology), Haifa, Israel

Israeli Society of Chemical Engineers \& Chemists

E-mail: alecgroysman@gmail.com

The aim of this work is to describe and analyze corrosion problems and their solutions in oil, gas, and refining industry. Corrosion phenomena and factors influencing them are discussed. Corrosion control and monitoring methods are illustrated. Corrosion management plays vital role in the solving of corrosion problems. The results are summarized in new book of the author "Corrosion Problems and Solutions in Oil Refining and Petrochemical Industry” published by Springer in 2016.

\section{INTRODUCTION}

Metallic equipment and constructions in oil, gas, and refinery plants contact crude oils, natural gas, petroleum products and fuels, solvents, water, atmosphere, and soil. All processes with participation of aggressive substances occur in metallic equipment at temperatures from $-196^{\circ} \mathrm{C}$ to $+1400{ }^{\circ} \mathrm{C}$ and pressures from vacuum to 1000 bar. Oil, gas and refinery units represent a high hazard industry with media which are flammable, explosive, toxic to human health or harmful to the environment. The combination of numerous factors makes oil, gas and refinery equipment very vulnerable to a variety of corrosion phenomena that can lead to serious accidents.

On the one hand, oil, gas and refining industry has accumulated large experience. On the other hand, the development and production of new deep wells in harsh conditions, introduction of new technologies, materials, strict requirements to the quality of gas and fuels, and to the reduction of environmental pollution state new problems to safe functioning of equipment and constructions. In order to understand and to solve corrosion problems, corrosion and materials specialist should learn diverse physicochemical processes which are the basis of treatment of oil and gas and production of fuels and other chemicals. Humans in this industry are responsible in $65-85 \%$ of corrosion events. Using proper corrosion management it is possible do diminish them.

There are many ways to avoid or control corrosion hazard: selection of corrosion resistant or suitable materials, correct design, use of anti-corrosive chemicals,

Cílem této práce je popis koroznich porblémů při zpracování ropy a plynu a jejich řešeni. Korozní jevy a faktory, které je ovlivňují, jsou diskutovány. Jsou nastíněny i možnosti korozního monitoringu a protikorozni ochrany. Korozni management hraje významnou roli př řešeni koroznich problémů. Výsledky jsou uvedeny v knize "Corrosion Problems and Solutions in Oil Refining and Petrochemical Industry”.

coatings, and cathodic protection, control of technological parameters, and what is very important, inspecting and control at all stages of application of these actions.

New generations of engineers come and face the problems which were solved and documented in books, standards, specifications, papers, proceedings, and reports. Most new information is dispersed in literature or is present in the heads of specialists like tacit knowledge. Our task is to dissimenate this knowledge. The present paper is a part of such program.

\section{Process units in oil, gas, refinery and petrochemical plants}

Like evolution of our planet, life and technology, oil, gas and refining industry has been developing with increasing complexity since its foundation in 1859 . There are associated facilities, such as cooling water systems, power plants (with water treatment and steam providing), and units related to the protection of the environment and humans (the utilization of hydrocarbon wastes, purification of wastewater and emitted gases, and deodorization). Any gas plant and oil refinery is a very complicated alive "organism". Each gas plant and oil refinery has its own unique processing scheme which is determined by the process equipment available, crude oil and natural gas characteristics, operating costs, and product demand. There are no gas plants and refineries absolutely identical in their operations but most corrosion problems and solutions may be similar. 


\section{Physicochemical properties and corrosiveness} of crude oils and natural gas

In order to understand corrosion problems and solutions in oil, gas and refining industry, we will describe physicochemical characteristics of crude oils, natural gas, fuels and their corrosiveness. Other media, such as water (cooling water, boiler feed water, extinguishing water, seawater), steam, different gases and chemicals also can participate in corrosion of equipment at oil, gas, and refining units.

Crude oil is a mixture of numerous liquid hydrocarbons containing dissolved gases, water, and salts. Crude oils are emulsions - drops of aqueous solution dispersed throughout the continuous hydrocarbon phase. Interstitial or connate water is always present in crudes. These water drops vary from almost fresh to saturated aqueous solutions of salts and are the main cause of crude corrosiveness. Crude oils in addition to hydrocarbons can include also compounds containing sulfur, nitrogen, oxygen, and metals. All these contaminants may be present in crude oils as dissolved gases, liquids and solids or distinctive phases. Microorganisms also can be present in crudes, water and fuels in active or dormant state. Every crude contains about the same kinds of compounds, but in different proportions. As a result, crude oil differ by their corrosiveness.

Natural gas is a homogeneous gaseous mixture of hydrocarbons (mostly), $\mathrm{N}_{2}, \mathrm{CO}_{2}, \mathrm{H}_{2} \mathrm{~S}, \mathrm{H}_{2} \mathrm{O}$, and traces of mercury, organic acids, and noble gases. Among these compounds, $\mathrm{CO}_{2}, \mathrm{H}_{2} \mathrm{~S}, \mathrm{H}_{2} \mathrm{O}$, mercury and organic acids can cause corrosion of metals at any stage of production, separation, handling, transportation, treating, and storage of natural gas. While water can contain salts in crude oil wells, water is pure in natural gas wells. Gases $\mathrm{CO}_{2}$ and $\mathrm{H}_{2} \mathrm{~S}$ containing in natural gas are dissolved well in this pure water that becomes acidic and corrosive. When $\mathrm{CO}_{2}$ causes corrosion it is called sweet corrosion. If $\mathrm{H}_{2} \mathrm{~S}$ is a reason of corrosion it is called sour corrosion. When $\mathrm{O}_{2}$ is a cause of corrosion it is called oxygen corrosion. Corrosion rates and intensity depend on the type and concentration (pressure) of aggressive ingredients, temperature, flow regime, and velocity.

\section{Corrosiveness of crude oils}

Chemistry of crude oils is so complicated and there are so many factors influencing corrosiveness of crudes that it is difficult and even in most cases impossible to predict their corrosiveness according to physicochemical composition. Usually corrosiveness of crude oils is defined by total acid number (TAN), total sulfur content, water and salt content, and microorganisms. The combination of these parameters and components influences corrosion by different manner and differently at stages of crude oil production, preparation, transportation, storage, and processing at refineries. Both TAN value and total sulfur content do not always define corrosiveness of crudes. For instance, $\mathrm{H}_{2} \mathrm{~S}$ and alkanethiols are corrosive to carbon steel, while thiophenes are not corrosive. The problem is complicated by the fact that $\mathrm{H}_{2} \mathrm{~S}$ and alkanethiols reacting with iron form iron sulfide scale which under particular conditions can be protective. Sometimes crudes containing relatively high water content can inhibit corrosion and, vice versa, crudes may be corrosive at relatively low water concentrations. Only experiment can respond on the question about corrosiveness of crudes.

\section{Corrosiveness of natural gas and other problems}

We will describe the effect of natural gas components on corrosion of metals.

Hydrogen sulphide $\left(\mathrm{H}_{2} \mathrm{~S}\right)$. The presence of sulfur compounds (mainly $\mathrm{H}_{2} \mathrm{~S}$ ) defines the gas to set the sour. Sweet gas contains less than 4 ppmv $\mathrm{H}_{2} \mathrm{~S}$ [1]. This value is the maximum approved one for the quality of natural gas during transportation in pipelines. $\mathrm{H}_{2} \mathrm{~S}$ can cause general and pitting corrosion, and hydrogen attack (because of acid corrosion). The latter can appear as crack or blisters. $\mathrm{H}_{2} \mathrm{~S}$ can be emitted through crack into environment and cause death of people and damage to the environment. Standards defining the conditions and requirements for using corrosion resistant alloys in the production and handling of natural gas that contains $\mathrm{H}_{2} \mathrm{~S}$ were developed and widely used [2-4]. The following methods of prevention of sour corrosion are used: control $\mathrm{pH}$ by caustic injection; injection of $\mathrm{H}_{2} \mathrm{~S}$ scavengers and corrosion inhibitors; organic and cement coatings; choose of alloys according to standard [2] for prevention SSC (Sulfide Stress Cracking).

Carbon dioxide $\left(\mathrm{CO}_{2}\right)$. When $\mathrm{CO}_{2}$ is dry in natural gas it is not corrosive. When $\mathrm{CO}_{2}$ is dissolved in water carbonic acid $\left(\mathrm{H}_{2} \mathrm{CO}_{3}\right)$ is formed. It is corrosive to carbon steel:

$$
\mathrm{Fe}_{(\mathrm{s})}+\mathrm{CO}_{2(\mathrm{~g})}+\mathrm{H}_{2} \mathrm{O}_{(\mathrm{l})} \rightarrow \mathrm{FeCO}_{3(\mathrm{~s})}+\mathrm{H}_{2(\mathrm{~g})}
$$

This sweet corrosion is widespread in natural gas pipelines. Passive black film $\mathrm{FeCO}_{3}$ is formed under particular conditions on the surface of carbon steel and low-alloy steels (to $9 \% \mathrm{Cr}$ ) and can protect from corrosion. Protective iron carbonate layer often breaks down because of high velocity stream and stresses. In this case, carbonic acid results in localized corrosion under the name "mesa" corrosion because the shape of the damage of the steel surface is similar to the shape of the mountains "Mesa", California, USA [5]. The following methods of prevention of sweet corrosion are used: injection of corrosion inhibitors (they are not effective at high temperatures); use of martensitic stainless steels $(>12 \% \mathrm{Cr})$; and control $\mathrm{pH}$ by caustic injection. 
Oxygen $\left(\mathrm{O}_{2}\right)$. It is the only impurity which is absent in natural gas reserves. Usually onshore and offshore lines of gas wells are connected to larger lines that bring gas to the plant. Sometimes gas collection systems operate under atmospheric pressure. As a result of leakage and opening valves, air can enter the system and cause corrosion. The appearance of oxygen corrosion is pitting. In addition to corrosion, oxygen at concentrations $>50$ ppmv can oxidize amines and glycols at appropriate units with formation corrosive substances, to influence inhibitor efficiency, to react with hydrocarbons during regeneration at high-temperature adsorption bed with water formation, to influence resistance of stainless steels to chloride SCC (Stress Corrosion Cracking), and galvanic corrosion. It is recommended not exceed oxygen concentration in natural gas above 10 ppmv. Oxygen causes corrosion of carbon steel and lowalloy steels, copper and its allloys. However, oxygen is required to keep protective oxide films on stainless steels, titanium, and aluminum. Philosophy of prevention from oxygen attack is to keep systems free of oxygen gas. There are the following methods of preventing oxygen penetration into natural gas systems, its removal and prevention from oxygen attack: maintenance of gaskets, rings, valves, pumps, compressors and other equipment and areas where the air can enter; keep positive pressure (above atmospheric pressure); blanketing with inert gas (e.g., nitrogen) above the surface of liquids in tanks; use of oxygen scavengers at low oxygen concentrations or catalytic reaction at high its quantities; deaeration; and use of coatings.

Organic acids (mainly acetic) can be present at high pressures in condensate and cause corrosion of carbon steel [6-8]. Acetic acid is a weak acid, but stronger than carbonic acid and participates in the occurrence of corrosion at the Top-of-Line corrosion (see below). Acetic acid may dissolve protective $\mathrm{FeCO}_{3}$ layer and accelerate corrosion.

Mercury is present in low concentrations in natural gas but can cause the following problems $[1,9,10]$. First, mercury is a toxic element to humans and the environment. Second, mercury can cause corrosion of aluminum heat exchangers at low temperatures at LNG (Liquid Natural Gas) units. Third, mercury can contaminate catalyst. Corrosion mechanism by mercury is unique and is called liquid metal embrittlement (a type of SCC). Mercury can be removed from aluminum surface using nitric acid or with steam or hot air. Mercury can attack also copper, nickel, zinc, iron, chromium, titanium, and zirconium. The only way to prevent corrosion by mercury is removal it from natural gas to a lower concentration than $0.01 \mathrm{mg}$ $\mathrm{Nm}^{-3}$ [1, 11-13].

Sediments in natural gas systems consist of sand, silicates, corrosion products (iron sulfides, oxides, hydroxides, and carbonates), sulfates, microorganisms and their metabolic products. These solids can appear in two ways: carrying along with a stream of natural gas or producing in physicochemical processes (e.g., corrosion). Pipes, tanks, pumps, compressors, filters, steam lines, boilers, reactors and other equipment can be damaged from sediments. Sediments can cause the following problems [14]: under deposit corrosion; blockages in pipes, pumps, filters, compressors, and heat exchangers; increase of pressure drop and as a result reducing the flow rate; erosion; reducing heat exchange; unplanned shutdowns for cleaning equipment from sediments; contaminate natural gas and other products; safety hazards and environmental problems. The solutions are the keeping correct process conditions and good maintenance with periodical cleaning of equipment from sediments.

Top-of-Line corrosion. During the transportation of natural gas in pipelines, water vapor condenses as the gas cools. $\mathrm{CO}_{2}$ is dissolved in water and $\mathrm{pH}$ decreases to 4 . Sometimes liquid water as thin layer remains on the inner surface of the upper part of pipeline, and severe localized corrosion occurs $[15,16]$. Usually this corrosion type occurs during wavy-stratified flow at velocity less than $3 \mathrm{~m} / \mathrm{s}$ and two phases exist: liquid and gas containing water vapor and $\mathrm{CO}_{2}$ and there are no materials (e.g., inhibitor) which can protect the upper inner surface of the pipeline. Shallow pits are formed and accumulated with sharp surface areas. Corrosion rate of top-of-line corrosion can reach $5 \mathrm{~mm} / \mathrm{y}$ [17, 18]. This happens because the heat exchange occurs between the pipe and the cold environment (river water, sea water or cold air) when the pipe is not thermally insulated. This type of corrosion occurs when there is condensation of water and concentrations of corrosive substances found naturally in the gas are able to create an acid environment on the internal surface of the pipe top. Aggressive substances are $\mathrm{CO}_{2}, \mathrm{H}_{2} \mathrm{~S}$, and organic acids (usually acetic acid) $[7,19]$. Water vapor present in natural gas cools and condenses at the increasing distances from compression station. Corrosion mechanism is corrosion by $\mathrm{CO}_{2}$ and a major factor is the rate of condensation but the $\mathrm{pH}$ value and flow regime also affect the corrosion rate and its stength. There is a critical rate of condensation of water vapor in gas pipelines $\left(0.15\right.$ to $\left.0.25 \mathrm{ml} \mathrm{m}^{-2} \mathrm{~s}^{-1}\right)$ for appearing top-of-line corrosion [20]. Various models were developed that allow to predict corrosion rates of carbon steel knowing condensation rate of water vapor and other parameters [21-27]. Ultra sound examination with flexible sensors is used for determination top-ofline corrosion [28]. The following measures are used for the prevention of this corrosion type:

a) Addition of corrosion allowance to the thickness of the tubes' wall during design.

b) Removal of water vapor from natural gas.

c) Implementation of thermal insulation on the tube surface. 
d) Using thick organic coatings.

e) Use of vapor corrosion inhibitors [29, 30].

f) Periodic cleaning using pigs and injection of corrosion inhibitors.

It is necessary to carry out corrosion monitoring of inner surfaces of pipelines.

\section{Influence of temperature on corrosion in natural gas systems}

Temperature and pressure affect the number of phases (liquid, gas, solid) which in turn can cause extraordinary corrosion [31]. Temperature rise accelerates the rates of electrochemical corrosion reactions and the transfer of participants: aggressive substances to the surface of metals and corrosion products from the surface to the environment. Increase of temperature causes a decrease of $\mathrm{pH}$ of water. As a result, corrosion rate should go up with the increase in temperature. On the other side, solubility of aggressive gases $\left(\mathrm{H}_{2} \mathrm{~S}, \mathrm{O}_{2}, \mathrm{CO}_{2}\right)$ decreases with increase of temperature. Therefore, temperature has complicated effect on corrosion rates. Up to a certain temperature, corrosion rate increases with increase of temperature. After a certain temperature, corrosion rate decreases due to the reduction of corrosive gases solubility in aqueous solutions. Usually maximum is at $60-80^{\circ} \mathrm{C}$ depending on the chemical composition of the liquid phase $[15,32]$. In addition to this, temperature increases the rate of sedimentation and the formation of a protective $\mathrm{FeCO}_{3}$ film.

\section{The effect of flow regime and flow rate on corrosion in natural gas systems}

Flow regime and flow rate affect the corrosion significantly. The increase in flow rate defines the coming of aggressive substances to metal surface, removing corrosion products and protective layers (such as corrosion inhibitors and $\mathrm{FeCO}_{3}$ ). As a result, corrosion rate increases. For example, increase of flow rate from 1 to $10 \mathrm{~m} / \mathrm{s}$ causes increase of corrosion rate from 1 to $3 \mathrm{~mm} / \mathrm{y}$ in aqueous solution containing $\mathrm{CO}_{2}(1$ bar and $20^{\circ} \mathrm{C}$ ) in the absence of protective layer $\mathrm{FeCO}_{3}$ [33]. The flow effect occurs especially in interferences such as valves, expansion lines, restrictions, elbows, and bends. Flow regime defines the type of wetting of the metal surface, resulting in the occurrence of corrosion at the top of the pipe. High flow rate can cause erosioncorrosion. At low flow rates, aggressive materials have sufficient time to be in contact with the metal surface, different deposits can accumulate and cause localized corrosion.

\section{Gas hydrates}

Ensuring of gas flow in the field of gas technology is very important. Natural gas flow should reach from the field to the production line without blockages. There are three areas of concern [1]: a) Wax deposits, asphaltenes, and other heavy organic materials.

b) Inorganic deposits.

c) The formation of solid gas hydrates (similar to ice) [34].

Organic deposits can be removed by means of "pigs". Inorganic deposits can cause problems of equipment in gas wells but not in large lines. Cleaning with acids is the solution for removing of inorganic sediments. Gas hydrates can clog and shut lines for a few minutes without warning. Sometimes they accumulate over months and years and can be set by the pressure drop. Gas hydrates are formed when water molecules form a cage structure and a molecule of methane or other gas are trapped inside. This happens at certain temperature and pressure. Molecules of other gases $\left(\mathrm{H}_{2} \mathrm{~S}, \mathrm{O}_{2}, \mathrm{~N}_{2}\right)$ containing in the natural gas can be included together with molecules of methane. Gas hydrates can be formed anywhere in the pipeline, but usually after orifices and valves due to significant cooling as a result of the expansion of the gas according to Joule-Thomson phenomenon. Three methods are used for preventing the formation of hydrates [1]:

a) Maintaining temperature and pressure outside of the formation of hydrates. Usually it is not practical.

b) Drying of natural gas from water.

c) Injection of inhibitors that prevent the formation of hydrates. Methanol and ethylene glycol at $~ 50 \%$ are commonly used for this purpose $[15,35]$.

\section{Corrosion control in natural gas systems}

Selection of corrosion control measures are based on the influence of chemical composition of natural gas (corrosive impurities) and process conditions (temperature, pressure, and flow rate regime) on corrosion. Three major factors affect corrosion: metal type, environmental features and conditions, and the border metalenvironment [14]. Thus, we take care of three factors above to prevent corrosion in natural gas systems. We classify all the methods into three groups: the metal treatment (selection of material), the treatment of the environment (neutralization, removing of water, $\mathrm{CO}_{2}$, $\mathrm{H}_{2} \mathrm{~S}, \mathrm{O}_{2}$ and salts) and boundary metal-environment (injection of inhibitors, use of coatings, and cathodic protection). We can add technological methods, which means maintaining the process conditions (temperature, pressure, flow rate). We will start from engineering design.

\section{Engineering design}

Engineering design includes:

a) The use of standards, specifications, procedures, reports, and any new information. 
b) The use of knowledge of principles, processes and possible corrosion phenomena in natural gas systems. It is necessary to take into account the geometry of the equipment, to make less crevices, to control flow rate, to prevent air infiltration, to avoid "dead legs" (gathering areas and stagnation of water).

c) Selection of suitable materials of construction, methods of protection, control and corrosion monitoring for designed period of service. Choosing suitable coatings, corrosion inhibitors, biocides, ant-scaling agents, cathodic protection and removing corrosive impurities $\left(\mathrm{H}_{2} \mathrm{~S}, \mathrm{H}_{2} \mathrm{O}, \mathrm{O}_{2}\right)$ belong to this group.

d) Selection corrosion monitoring methods: monitoring for construction materials behavior, corrosive environment and efficiency of methods of protection against corrosion.

\section{Selection materials of construction}

Materials selection marks the use of metals and alloys, polymer and composite materials (composites) suitable for different environments in the technology of natural gas. There is no ideal material that is resistant to all media under all conditions. It is acceptable to call stainless steels and alloys based on nickel as corrosion resistant materials. Really general corrosion rates of these alloys in natural gas systems are much lower than values for carbon steel. But stainless steels and nickel alloys are susceptible to pitting and crevice corrosion, intergranular corrosion, and stress corrosion cracking. Therefore, it is better to use the term materials compatible with corrosive media. A proper method for selecting alloys is based on information and experience which are included in the standards, procedures, reports, and articles. The disadvantage of this approach is that changes in the environment (even at the same gas field) can alter the corrosion resistance of alloys. In the selection of alloys, it is necessary not only to relate to general corrosion but also to local corrosion, for example, by chlorides, oxygen, bacteria, hydrogen, etc.

Metals and alloys. Carbon steel occupies more than $90 \%$ of all the materials in natural gas systems. Drill pipes are used according to the standard API 5D, casings and tubes - API 5CT, and linepipes - API 5L [5]. Design of carbon steel use should be made with calculation of corrosion allowance [32] and suitable heat treatment. Use a carbon steel in natural gas systems must be accompanied by injection of corrosion inhibitors to prevent internal corrosion, the use of coatings, and cathodic protection to prevent external corrosion of underground and submerged structures and equipment. It is possible to use materials resistant to corrosion better than carbon steel: metals and alloys with addition of chromium, nickel and molybdenum (stainless steels), alloys based on nickel, cobalt, copper, titanium, and aluminum, polymers, and composite materials [36-38].
The most common alloy among stainless steel in natural gas systems is $13 \mathrm{Cr}$ that is used in wells and in sea water. Generally selection of alloys for use in hot gas wells and other applications occurs in the next direction [5]: carbon steels $\rightarrow$ stainless steel martensitic $13 \mathrm{Cr} \rightarrow$ $\rightarrow$ stainless steels austenitic $\rightarrow$ duplex stainless steels $\rightarrow$ $\rightarrow$ austenitic nickel alloys. It is possible to select specific alloy suitable at particular temperature, pressure and $\mathrm{CO}_{2}, \mathrm{H}_{2} \mathrm{~S}$ and $\mathrm{NaCl}$ concentrations when the general corrosion rate will be less than $0.05 \mathrm{~mm} /$ year [38]. Titanium alloys can be used in natural gas wells at high pressures and temperatures in the presence of $\mathrm{H}_{2} \mathrm{~S}$ and $\mathrm{CO}_{2}$ [39]. Iron-nickel (9\%) alloys are used as material for cryogenic tanks for storage of liquefied natural gas (LNG) at $-162^{\circ} \mathrm{C}$.

Polymeric materials and composites occupy a certain place in their application in natural gas systems $[5,40,41]$. Chemical resistance of these materials is a much higher in contact with various gases and solvents. The disadvantages of polymers are low resistance to high temperatures and low mechanical properties compared with metals. Polymeric materials are used in natural gas systems as seals, gaskets, rings, sumps, tanks and pipes in contact with water, sea water, cooling water, fire-fighting water, solutions of acids and alkalies, atmosphere, and soil. Polymeric materials are characterized by mechanical, thermal, electrical properties, and chemical resistance. Temperature drastically affects the properties of polymers and composites. When heating the polymer material can chemically breakdown. When cooling it can be hard and brittle. Selection of the type of polymer and composite depends on the purpose for use in natural gas systems. Therefore, it is necessary to analyze all properties of polymers and composites before application. Polymeric materials and composites are used in coatings.

\section{Coatings}

Use of any coating is based on the fact that metal must be isolated from the aggressive environment. All coatings can be differentiated into three groups according to the nature of basic material: organic, inorganic, and metallic [32]. Organic coatings may be paints, polymeric materials, greases, and other paraffinic mixtures. Inorganic coatings may be enamels, ceramics (among them cement), and glasses. Metallic coatings are any metal or alloy. All three groups of these coatings are used for the protection of pipes, tanks, pumps, columns, numerous structures and equipment in contact with natural gas, atmosphere, water, soil, and different technological solutions. Natural gas systems are situated in different geographical areas. Therefore, it is important to create coating specifications that protect structures and equipment under various conditions: resistant to gas, fuels, water and aqueous solutions, atmosphere, soil, high temperature, and under thermal insulation [42]. 


\section{Cathodic protection}

The philosophy of cathodic protection use is that organic coatings' application on metallic structures is the main (leading) method of corrosion control, and cathodic protection is a complement to protect the defects that are always exist or appear in organic coatings during application and service. Electrochemical mechanism of corrosion of metals in solutions of electrolytes allows the use of electric current and electric potential to protect metal surface from corrosion. Therefore, cathodic protection works only in solutions of electrolytes and does not work in media of high electrical resistivity which cannot conduct electrical current: in natural gas, air, oil, and fuels. Two ways exist for cathodic polarization in practice: connection the main metal to be protected (for example, iron) to less noble metal (aluminum, zinc, magnesium, or their alloys), or connection to the negative pole of outer power supply (rectifier or battery). The first method is based on sacrificial anodes use, because they are sacrificed being dissolved as anode, and turn the metallic construction to cathode which does not corrode. Sometimes this method of cathodic protection is called a passive one (there is no relationship to passivity!), because we connect equipment to be protected to sacrificial anode, and "forget" about corrosion for some period. The second method of cathodic protection is based on the connection to the negative pole of the rectifier and use of impressed electric current. This method is called sometimes an active method of cathodic protection. Cathodic protection is one of wide spread methods of corrosion control of underground and submerged metallic structures and equipment. Cathodic protection works only on external surfaces that contact with the electrolyte and it does not mean the media flowing or stored inside: gas, oil, fuel, or water. Many standards exist to implement cathodic protection, testing methods and monitoring efficacy [43-50]. High temperatures, destroyed coatings, shielding, microbial attack, areas of pipes and tanks that are not in contact with the electrolyte and dry soil are the conditions when cathodic protection is not effective or is working only a part of time. Cathodic protection does not work for thermal insulating structures [47]. It is important to remember that cathodic protection is working when the following components exist: an anode, a cathode, an electrolyte, and a complete electrical circuit. The absence of one of these components prevents the activity of the cathodic protection. Sometimes people forget about it and try to use cathodic protection for hot pipes when hot water evaporates and there is no electrolyte for the passage of an electric current. American engineer Robert Kuhn was the first who used cathodic protection on pipelines for transporting natural gas in the U.S. in 1928 and more widely in the 1930s [5, 51-54]. There are several methods to test the efficacy of cathodic protection $[5,32,42,43]$.
The most common method is to check the electrical potential of the protected pipe. Its corrosion rate decreases to two orders of magnitude when electric potential lower than $-0.85 \mathrm{~V}$ with respect to a saturated copper/copper sulfate reference electrode [5, 32]. Keep in mind that the corrosion rate of cathodically protected structure is never zero but very low value and acceptable for safe use without corrosion risk. In the early years (1920-1950) of use of cathodic protection, it was generally accepted that corrosion structures could be fully protected in soil and water. Then cathodic protection was begun to use in combination with coatings. Cathodic protection is not an alternative to the protection by coatings of pipes and tanks but an addition. Coatings allow to reduce electric current on several orders of magnitude and to extend the service life of structures.

It should be noted that cathodic protection can be used for the protection not only carbon steel but also cast iron, ductile iron, stainless steel, brass, and aluminum [43]. Cathodic protection can cause the following problems [32]:

a) Impressed current systems may cause stray current corrosion if metallic constructions are in the region of cathodic protection activity and are not connected to impressed current.

b) Coating debonding.

c) Hydrogen embrittlement (in the case of overprotection, less than $-1 \mathrm{~V}$ with respect to a saturated copper/ copper sulfate reference electrode and as a result of water decomposition and hydrogen evolving).

d) Corrosion of aluminum (because hydroxyl ions forming during cathodic protection are harmful to aluminum).

\section{Change of chemistry of the environment}

There are several options to change the chemical composition of the environment and protect metals. These methods are injection of corrosion inhibitors, biocides, $\mathrm{pH}$ control, removal of water, $\mathrm{CO}_{2}, \mathrm{H}_{2} \mathrm{~S}$, and $\mathrm{O}_{2}$ from natural gas.

Corrosion inhibitors occupy an important role in preventing and reducing corrosion in natural gas systems. The first inhibitors were amines that were used as the only means of corrosion control in natural gas pipelines in the 1940-1980s. Only in the 1980s with the discovery of deep wells at high temperatures and high pressures inhibitors were not effective, and special alloys were begun to use under these conditions. There is no common classification of inhibitors. We will describe a few of them.

a) Classification according to the influence on corrosion reactions. For example, anodic inhibitors slow down anodic rections on the surface of the metal. Cathodic inhibitors retard cathodic reactions. There are mixed 
inhibitors that supress both anodic and cathodic reactions simultaneously.

b) Classification by the type of metal to be protected. For example, corrosion inhibitors that protect carbon steel, copper, aluminum and their alloys.

c) Classification by the environment: water and aqueous solutions of electrolytes; acids; alkaline solutions; the gaseous phases; oil and fuels; coatings; concrete.

d) Organic and inorganic inhibitors.

Mechanism of action of inhibitors is based on their adsorption on the metal surface and preventing the coming of aggressive substances to the metal surface. Therefore, usually increase of concentration of inhibitors reduces the metal area exposed to aggressive components. We will describe corrosion inhibitors using in natural gas systems. Most corrosion inhibitors using in gas systems are "filming amine" that produce a protective film on the metal surface [32, 42, 55-57]. When crude oil enters into an aqueous phase its ingredients are able to protect the inner surface of the pipes from corrosion [58-61]. Organic compounds containing nitrogen (amines, amides and their salts), heavy carboxylic acids and their salts, imidazoline, phenols, thiourea, phosphonates, benzoates, saturated hydrocarbons, aromatics and resins containing in oils act as corrosion inhibitors [57, 59, 62]. Most corrosion inhibitors injecting into natural gas pipelines are nitrogenorganic substances [57, 63]. Inhibitors are not always able to prevent corrosion at the top of the pipelines. Volatile corrosion inhibitors [62] and inhibitors that are introduced into the foam matrix [27] are recommended in these cases. Inhibitors produce a thin layer of molecules on the surface of the metal. An intensive flow of gas, liquid or liquid-gas mixture is able to remove this layer. Inhibitor efficiency decreases in the presence of suspended solids and sand because they attract molecules of the inhibitors. Inhibitors are attracted to scale and corrosion products that reduce their effectiveness. It is recommended to carry out chemical cleaning before the start of corrosion inhibitor injection. It is necessary to carry out periodic cleaning using "pigs". Inhibitors using in natural gas systems are organic materials that decompose at temperatures above $200^{\circ} \mathrm{C}[5,57]$.

Injection of methanol or ethylene glycol to prevent the formation of gas hydrates also inhibits corrosion due to dilution of aqueous phase. Inhibitors should function in accordance with other chemicals injecting into gas systems for various purposes. We can start or replace inhibitors without stopping and disruption of a process of production, transportation, and manufacturing. This is a big advantage over other methods of corrosion control. In addition, continuous monitoring of the efficiency of inhibitors can be performed and it is possible to change their concentrations in accordance with changes of corrosivity of natural gas.
Cooling water systems. Three chemicals are injected in these systems for control of corrosion, microbiological growth and scale formation: corrosion inhibitors, biocides, and anti-scaling agents. Corrosion inhibitors in such systems are mixtures of anodic inhibitors (e.g. phosphates), cathodic inhibitors (e.g. zinc salts), organic inhibitors (e.g. phosphonates), and copper corrosion inhibitors (azole). We can use inorganic inhibitors $\left(\mathrm{NaNO}_{2}\right.$, $\mathrm{Na}_{2} \mathrm{SiO}_{3}$ ) in closed cooling water systems for chilling pumps and compressors [32]. Sodium nitrite protects carbon steel in fuel-water mixtures [42].

Now there is a tendency to use "green" or "environmentally friendly" inhibitors [42, 64]. They should be evaluated in terms of health, safety and damage to the environment. It is important to assess the efficiency of potential inhibitors in laboratory and in field in order to select a suitable inhibitor for particular natural gas well [65-68]. We can calculate efficiency (E\%) of inhibitors according to the following formula [32]:

$$
E, \%=\frac{C R_{0}-C R_{i}}{C R_{0}} \cdot 100 \%
$$

where $\mathrm{CR}_{\mathrm{o}}$ and $\mathrm{CR}_{\mathrm{i}}$ - the corrosion rate of metal without and in the presence of inhibitor respectively. Corrosion rate can be measured using the method of "weight loss (coupons)" or "electrical resistance (ER-probes)" [32, $42,68]$. The dosage should be chosen very carefully and then keep it in the system. Any change in dosage can affect the efficiency drastically. Inhibitors are injected continuously or in portions periodically. The first dose is always big to cover the entire surface of the metal. Then we can lower its concentration to the minimum necessary to maintain inhibitor layer on the metal surface. Corrosion monitoring by means of coupons or electrical resistance (ER-probes) is used to check the efficiency of inhibitors and to change its concentration if needed. It is important to install sensors and coupons inside pipeline in places that could be affected by corrosion and scale and to follow all internal space of the tube $[69,70]$. We have to take into account that corrosion is a random process and can vary from place to place and over time. It is necessary to combine coupons and ER-probes that are complementary to each other. We should take into account the natural gas field can age, and chemical composition, temperature and pressure can vary with time. As a result, corrosiveness of natural gas can also change.

\section{Corrosion monitoring in natural gas systems}

It is important to follow the corrosion in natural gas systems because there is a high danger to humans and the environment in the case of holes and leaks of toxic and explosive gases. The philosophy of preventive anti-corrosion methods also intends to follow their effectiveness. The purpose of corrosion monitoring is 
to monitor corrosion situation of metallic equipment and structures, aggressiveness of the environment, and effeciency of corrosion control measures. There are several ways to classify corrosion monitoring methods. For example, direct and indirect methods. Direct methods of measurement belong to parameters that vary directly from corrosion. For example, a wall thickness of the pipe or a mass of a metal coupon. Indirect methods of measurement belong parameters which influence indirectly (temperature, pressure, $\mathrm{pH}$, concentrations of aggressive substances to metals) or are affected (metal dissolved ions because of corrosion and detection of leaking gases or liquids due to holes caused by corrosion). Direct methods are divided into intrusive methods (e.g. weight loss) and nonintrusive (for example, the wall thickness measurement). Indirect methods can be online and off-line. Online measurements are performed without removal of the sensor from the process. Off-line method means removing a metal sample from the process stream for testing. We should distinguish between corrosion monitoring and inspection. Monitoring allows to measure corrosion parameters in real or approximately real time. Inspection has time delay between an incident and an investigation. Inspection collects data about the event that has already happened. We classify corrosion monitoring methods on physical methods, test methods of the environment (chemical analytical) and measures the border metal-environment [32, 71, 72].

\section{Physical methods of control of properties of metals}

Historically, physical methods were first: the human eye, sometimes with a magnifying glass. Now there are many optical devices: video cameras, microscopes, stereo video microscopes, and borescope [32, 42, 72]. They can be used for examination of corroded metal surface. Different devices and techniques based on physical phenomena are used for measuring the wall thickness of pipes and tanks in natural gas systems: Ultrasonic Technique, Acoustic Emission, Eddy Current Technique, Magnetic Flux Leakage, and radiographic methods (X-ray). In addition, there are other physical methods: Infrared thermography, chemical analysis (non-destructive) of alloys on the site, and penetrant testing $[32,42,72]$.

Weight Loss (WL) method is based on inserting of a metal sample (called coupon) of a known mass and area into a flow process, immersion for a certain period (usually between 30 to 300 days, and time depends on the aggressiveness of the environment), removing, cleaning from corrosion products and other deposits, and weighing. A loss of coupon weight per unit area during some period is the rate of corrosion of a metal in a specific environment. Weight loss method is standardized $[69,73-76]$ and the most accurate among all the existing methods of corrosion monitoring.
Electrical Resistance (ER) method is based on measuring the electrical resistance of the sensor (corrosometer) made from the same metal of a tube (or other equipment) with time. Corrosion of the sensor (decrease of thickness of a sensor and respectively cross-sectional area A) causes increase of electrical resistance $R$ of a sensor material:

$$
R=\frac{\rho \cdot L}{A}
$$

where $R$ - the electrical resistance of conducting material (sensor), Ohm; $\rho$ - the specific electrical resistivity of conducting material, $\mathrm{Ohm} \cdot \mathrm{m} ; L-$ the length of a sensor, $\mathrm{m} ; A$ - the cross-sectional area of a sensor, $\mathrm{m}^{2}$. ER-method is an analog of weight loss method with advantage that corrosion rate can be measured continuously. Special 'flush' probes are used in pipelines when cleaning and inspection is performed by means of 'pigs' in natural gas systems when multiple liquid-gas phase is flowing inside [77]. This method is standardised [78]. We can use ER-probes up to $537^{\circ} \mathrm{C}$ and 700 bar $[32,42]$. Both methods (WL and ER) are used for corrosion monitoring in natural gas systems because there is no restrictions on the electrical conductivity of the environment. We can use these two methods for measuring of corrosion rates of metals in gases, in air, and in conductive and nonconductive solutions. There is a restriction of physical methods: they assume that the corrosion rate is constant throughout the measurement period. In fact, failure because of corrosion occurs rarely with a steady rate. In most cases, failures occur suddenly and often relate to operational events: shutdown of facilities, changes in temperature, pressure, concentrations of substances, velocity and flow regime, operating system, etc.

\section{Monitoring of the environment and technological parameters}

Environmental testing includes chemical analytical, physicochemical, physical, and microbiological methods $[14,32,42,72]$. These methods are used to determine aggressive components in the environment: $\mathrm{pH}, \mathrm{CO}_{2}$, $\mathrm{H}_{2} \mathrm{~S}, \mathrm{O}_{2}, \mathrm{Cl}^{-}, \mathrm{SO}_{4}{ }^{2-}$, suspended solids, hardness, corrosion inducing bacteria, and particles that cause erosion. On the other hand, physicochemical analytical methods (Inductively Coupled Plasma and Rotated Disc Electrode Atomic Optical Emission Spectroscopy) are used for determination of concentration of metals which corroded in liquids with sensitivity $\sim 1 \mathrm{ppm}$ and less. Physical and chemical analytical methods should be integrated in natural gas systems. The question is what is the dangerous values of chemical analytical parameters which define the intensity of corrosion (high or low) in the system? Allowable values depend on the specific system (type of a metal and the environment) and corrosion phenomenon type. 
Gas detectors have been developed (PID - photoionization detectors) which can detect hydrocarbon gases at concentrations of $1 \mathrm{ppb}[79,80]$. These gas detectors are lightweight and portable.

In many cases, it is important to follow not after absolute values, but after a trend that can suddenly change, and thus we can detect the start of corrosion. Testing of concentrations of corrosion inhibitors, neutralizers, oxygen and hydrogen sulfide removers (scavengers), and biocides in different media and water drainage are important in determination of the efficiency of treatment against corrosion and for the environment.

Monitoring of technological parameters includes measurement of flow rate, temperature, pressure, and dew point temperature.

Advantage of physicochemical analytical methods is their highly sensitivity.

The disadvantages are that the chemical composition of the environment points on a qualitative assessment of corrosion; the presence of corrosion products on metal surface can lead to wrong results; sometimes these methods require a long time to obtain results.

\section{Examination of the border metal-environment}

These methods are based on physicochemical properties of the border metal-environment and include electrochemical methods, identification of corrosion products and other deposits on metal surface, and surface morphology of corroded metal. Electrochemical methods (examination of electrical potential and current) can be used only in solutions of electrolytes. These methods are used for monitoring of the efficiency of cathodic protection of underground and submurged pipelines, tanks, and other structures.

Physicochemical methods, such as Scanning Electron Microscopy (SEM), Tunneling Scanning Microscopy (STM), Atomic Force Microscopy (AFM) are used for examination of the surface morphology of the metal; Energy Dispersive Spectroscopy (EDS), Energy Dispersive X-ray Fluorescence (ED-XRF), X-ray photoelectron spectroscopy are used for identification of corrosion products, deposits and inhibitors on the metal surface. Microbiological testing of deposits and different media is very important to determine the causes of MIC and ways to prevent it.

\section{On-line, real-time corrosion monitoring}

On-line measurements are continuous measurements of weight loss and corrosion rate of metals, physicochemical parameters of the system and the environment; data are obtained without disruption of the monitoring processes. Off-line measurements are periodic measurements with a disruption of the monitoring process. Real-time information is obtained immediately, usually for a few minutes. Continuous real-time corrosion monitoring of pipelines is mostly developed
$[42,72]$. It is necessary to perform its integration with process control system, which means to follow technological parameters with corrosion-state data. Here are some corrosion monitoring systems of pipelines [42]:

a) The Resistance Corrosion Monitoring (RCM) - continuous measurements of pipe wall thickness using the method of 'electrical resistance'.

b) The Field Signature Method (FSM) - Electrical resistance method for determining the wall thickness of pipes: uniform corrosion, corrosion pits, erosion, and cracks.

c) Advanced ER on-line corrosion probes with fiber optic communication links - Monitoring the effectiveness of anticorrosive chemical injections [77].

d) In-Line Inspection (ILI) - Survey for evaluating corrosion of pipes and damages [81].

Combination of physical techniques, chemical analytical and physicochemical methods gives wide information of corrosion situation in natural gas pipelines.

\section{Monitoring of efficiency of cathodic protection}

Monitoring and examination of the effectiveness of cathodic protection of pipelines are defined in standards $[43,82,83]$. In practice, two criteria for definition of efficiency and integrity of cathodic protection are used. The first criterion is the electrical potential of a protected buried pipeline in soil should be less than $-0.85 \mathrm{~V}$ with respect to a saturated copper/copper sulfate reference electrode (see page 105). The second criterion is a minimum of $0.1 \mathrm{~V}$ of cathodic polarization between the structure surface and a stable reference electrode contacting the electrolyte [43].

Close Interval Potential Survey (CIPS) and Direct Current Voltage Gradient (DCVG) are widely used for examination of efficiency of cathodic protection of underground pipelines [84-87]. DCVG method is based on the potential difference measurements at distances of about one meter above underground pipe that is protected by cathodic protection. The more dimensions of defect in coating, the more the difference in potentials. This method allows to detect defects $\sim 1 \mathrm{~cm}$ in coatings on pipes buried in the ground at a depth of 1-2 meters.

\section{Legislation}

Important documents have been recently published that outlined significant changes to the Pipeline Safety Regulations that are intended to increase the safety of onshore natural gas transmission and gathering pipelines across the USA [88-90]. The proposed rule broadens the scope of safety coverage by adding new assessment and repair criteria for gas transmission pipelines located in areas of medium population density where an incident can pose risk to human life. This rule addresses cracking defects, corrosion metal loss and other defects; 
requirements for monitoring gas quality and mitigating internal corrosion, for external corrosion management programs including aboveground surveys, CIPS, and electrical interference surveys. The first step is materials validation [90]. For this, a design formula is used that accounts for the pipeline's specified minimum yield strength, wall thickness, and diameter multiplied by the class location factor, which is based on population density and the number of residents living within close proximity of the pipeline. For the second step, hydrostatic testing or other approved methods must be used to validate the lengths of pipe that have missing information.

\section{Conclusion}

Nondestructive testing and corrosion monitoring are important measures in detection, prediction and prevention of corrosion in natural gas systems. We should distinguish between corrosion monitoring, inspection, and survey. Inspection and survey operations are planned and carried out periodically. Corrosion monitoring is carried out continuously to obtain realtime information. Nondestructive testing and corrosion monitoring are interdisciplinary issues encompassing wide areas including different techniques, sensors, instruments, data analysis, and use of standards. The more we use various methods and means the more we get complete and up to date picture of corrosion situation. A selection of corrosion monitoring methods depends on the type of equipment or structure, conditions, and objectives. Therefore, there is no absolute and ready proposal for all systems and all cases. It is necessary to use corrosion monitoring methods as much as possible. Using of NDT and corrosion monitoring can reduce the risk of failures almost to zero. Sometimes visual inspection gives no warning to significant failure that requires high cost of repairs in a short time. Therefore, we need continuous monitoring in real time. There is no technology that can detect and immediately inform all kinds of corrosive failures. It is necessary to design and implement NDT and corrosion monitoring methods at the stage of a project design. It is very important to select points of inspection, testing and installation of sensors and coupons. It is recommended to measure the thickness using ultrasonic methods in places where corrosion sensors are installed. Corrosion rates (even uniform corrosion) can vary at different distances and places of equipment and structures. The more locations will be covered by corrosion sensors the more we define and know real corrosion situation.

We should not talk about the cost of corrosion monitoring techniques. This cost is approximately $0.05 \%$ of the overall losses of corrosion damage [42]. When corrosion failure occurs the cost of failure (corrosion loss) can be thousands of times higher than the cost of corrosion monitoring methods. Data of NDT methods and corrosion monitoring (thickness and corrosion rates) enter and appear on a computer screen as other technological parameters: temperature, pressure, flow rate, and concentrations of chemicals.

There is a similarity between the corrosion rates and the behavior of the stock market: data in the past do not give guarantee for the future. Any change in the process (temperature, installation of an additional pump, changing the diameter of the pipe, adding a heat exchanger, flow regime, type of environment, inhibitors, neutralizers, and other chemicals) can cause sudden corrosion. Therefore, it is necessary to analyze all the changes in the system and how they affect corrosion. In light of this, corrosion monitoring and NDT methods represent an important role in preserving of metal equipment and structures in good condition and preventing damage to humans and the environment.

\section{Physicochemical basics of corrosion at refineries' units}

Corrosion of metallic equipment and structures at refineries' units occur in different media and phases under wide conditions. It is possible to divide corrosion at refineries' and petrochemical units into five groups:

Low temperature $\left(\mathrm{T}<100^{\circ} \mathrm{C}\right)$ corrosion in the presence of electrolytes, usually water and aqueous solutions of electrolytes, such as dissolved corrosive gases (e.g., $\mathrm{HCl}, \mathrm{H}_{2} \mathrm{~S}$, and $\mathrm{NH}_{3}$ ), or dissolved salts (e.g., $\mathrm{NaCl}$ and $\mathrm{Na}_{2} \mathrm{SO}_{4}$ ).

High temperature $\left(\mathrm{T}>200^{\circ} \mathrm{C}\right)$ corrosion by nonelectrolytes, usually gaseous $\mathrm{H}_{2} \mathrm{~S}$ and $\mathrm{H}_{2}$; naphthenic acid corrosion; hot ash corrosion; oxidation by oxygen in furnaces).

Intermediate temperature $\left(100^{\circ} \mathrm{C}<\mathrm{T}<200^{\circ} \mathrm{C}\right)$ corrosion which can occur either in the presence of electrolytes (e.g., amines) or non-electrolytes $\left(\mathrm{SO}_{2}, \mathrm{SO}_{3}\right)$ depending on substances and conditions.

Corrosion in natural environments: in the atmosphere, soil, and natural waters.

Specific corrosion phenomena: acid dew point corrosion, corrosion under thermal insulation, boiler feedwater corrosion, and steam condensate corrosion.

\section{Low-temperature corrosion}

Most low-temperature corrosion problems in oil refineries and petrochemical plants are not caused by hydrocarbons that are processed but by various inorganic compounds, such as $\mathrm{H}_{2} \mathrm{O}, \mathrm{H}_{2} \mathrm{~S}, \mathrm{HCl}, \mathrm{NH}_{3}, \mathrm{NaOH}, \mathrm{H}_{2} \mathrm{SO}_{4}$, $\mathrm{Na}_{2} \mathrm{CO}_{3}$, and dissolved oxygen. Organic acids that are contained or occasionally formed in hydrocarbons and amines using as neutralizers and corrosion inhibitors in the overhead of distillation systems may also promote low-temperature corrosion. There are two sources of 
compounds causing corrosion: contaminants contained in crude oil and process chemicals. Prolonged use of aqueous solutions of amines for the absorption of acid gases $\mathrm{H}_{2} \mathrm{~S}$ and $\mathrm{CO}_{2}$ at amine treating units can result in formation of corrosive heat stable amine salts. Use of sulfolane for a long time also can cause formation of destructive corrosive products (acids) at petrochemical plant. Electrochemical mechanism is realized in lowtemperature corrosion phenomena.

\section{High-temperature corrosion}

High-temperature $\left(\mathrm{T}>200^{\circ} \mathrm{C}\right)$ corrosion pertains to the second large group of corrosion phenomena which occurs when exposed to non-electrolytes: sulfidic corrosion (named also sulfidation - oxidation by $\mathrm{H}_{2} \mathrm{~S}$, $\mathrm{S}_{8}$, and some other sulfur compounds,), naphthenic acid corrosion (NAC), hydrogen attack, hot ash (fuel ash or salt deposit) corrosion, oxidation (by oxygen gas), carburization, and 'metal dusting'. Non-electrochemical mechanism is realized in these corrosion phenomena. Non-electrolytes are generally gases (e.g., $\mathrm{H}_{2} \mathrm{~S}, \mathrm{H}_{2}, \mathrm{O}_{2}$, and hydrocarbons) or liquids (e.g., naphthenic acids or $\mathrm{S}_{8}$ ) at high temperature. Sometimes these corrosive components are present together. In these cases, we should analyze sulfidic corrosion with the presence of $\mathrm{H}_{2}$, and NAC in the presence of $\mathrm{H}_{2} \mathrm{~S}$. Such situations complicate corrosion mechanism and under particular conditions can either induce or decrease corrosion. For example, sulfidic corrosion proceeds more intensively in the presence of $\mathrm{H}_{2}$, and inhibition of NAC occurs by sulfide scale formed in the presence of $\mathrm{H}_{2} \mathrm{~S}$. Sulfidation and hydrogen attack are most dangerous corrosion phenomena because can lead to catastrophic unexpected pipe rupture, releasing flammable media, fires, explosions, and injuries $[91,92]$.

\section{Corrosion problems and solutions at oil, gas, refinery and petrochemical units}

Corrosion problem solving is an identifying of problems and their solutions. It includes the following steps:

a) Identifying the problem.

b) List all the reasons of the problem.

c) List all the factors of the problem.

d) Try to think of realistic solutions that take all the factors of the problem into account. There is usually more than one solution.

e) Choose the solution that you think is best and try it.

f) Evaluate the result of your solution. Did it solve your problem? If not, try another solution.

At first glance a methodology of solving the problem is clear. However, in many cases it requires interaction and rapport of many divisions, departments, and subdivisions: purchasing, production, inspection, and laboratories. What is important that people of different specialties should take part in solving most problems.

Because of specific media and conditions in oil, gas, refining and petrochemical industry in addition to general corrosion phenomena (in water, atmosphere, soil, at high temperatures) occurring in any industry there are particular corrosion problems intrinsic only to them. They are: corrosion in crude oils and natural gas systems, petroleum products and fuels, sulfidic corrosion, hydrogen attack, naphthenic acid corrosion, sour water corrosion, corrosion in amine solutions, and polythionic acid corrosion. Specific corrosion problems of sulfur compounds, naphthenic acids, hydrogen gas, and amine solutions which we can face with at high temperature and their solutions are presented in $[5,14$, 42, 93-95]. All 15 known corrosion phenomena may occur in oil, gas, refinery and petrochemical units: general, pitting, crevice, galvanic, MIC, dealloying, intergranular corrosion, stress corrosion cracking (SCC), hydrogen attack, erosion, cavitation, impingement attck, fretting corrosion, corrosion fatigue, and exfoliation. Many practical examples and their solutions are given in $[14,32,42]$.

\section{Corrosion by sulfur compounds}

Sulfur compounds play essential role in corrosion of the equipment at oil refining and petrochemical units. For our convenience, we will distinct low-temperature $\left(\mathrm{T}<100-200^{\circ} \mathrm{C}\right)$ and high-temperature $\left(\mathrm{T}>200^{\circ} \mathrm{C}\right)$ corrosion with the participation of sulfur compounds. Hydrogen sulfide can participate in low- and hightemperature corrosion. Low-temperature corrosion in the presence of dissolved $\mathrm{H}_{2} \mathrm{~S}$ in aqueous phase, corrosion by ammonium bisulfide, sulfuric acid and polythionic acids can occur at $\mathrm{T}<100^{\circ} \mathrm{C}$. Corrosion by sulfur compounds at high temperatures is discussed below.

\section{Sulfidic corrosion}

Sulfidic corrosion is corrosion of metals and alloys by particular sulfur compounds at high temperatures, usually in the range $230-540^{\circ} \mathrm{C}[96,97]$. Not all sulfur compounds oxidize metals and alloys. Even some of them, thiophenes and sulfones, can inhibit corrosion of metals [93]. Their corrosiveness is realized under appropriate concentrations and temperatures, and is differently manifested on various alloys, even steels. The mechanism of sulfidic corrosion is the direct chemical oxidation of metals by sulfur compounds. The sulfidation mechanism is closely akin to air oxidation and the same alloying elements provide resistance to attack. Carbon steel, low-alloy Cr-Mo steels, nickel, copper, zinc and their alloys are attacked by sulfur compounds at elevated temperatures. High-nickel alloys are most susceptible 
to sulfidation. Increasing chromium in iron-, nickel-, and cobalt-base alloys improves sulfidation resistance. Chromium and aluminum alloys are resistant to sulfidic corrosion. Sometimes severe sulfidation even occurs when the total sulfur content in hydrocarbon feed (e.g., naphtha or LPG) is very low (10-20 ppm) [98]. Iron sulfide can promote the adhesion of coke to the surface. In addition, iron sulfide can act as dehydrogenation catalyst to promote the formation of coke by asphaltenes $[99,100]$.

\section{Naphthenic acid corrosion}

The oil refining industry has seen a trend toward refining more highly acid crude oils since the early 1990s. This tendency also remains nowadays. The global supply of high acid crudes will increase fourfold since 2000 to 2020 [36, 101]. There are about 100 acidic crude oils (TAN $>0.5 \mathrm{mg} \mathrm{KOH} / \mathrm{g}$ oil), and their geography is very diverse [102-104]. Naphthenic acids (NA) are not corrosive at ambient temperatures and their aggressiveness is materialized at $190-400^{\circ} \mathrm{C}$. NA containing in acid crudes can cause diverse problems in oil refining industry: formation of stable emulsions and fouling; appearance of nonextractable chlorides; environmental problems; diminishing inhibitor efficiency; and corrosion. Therefore, interest to NA is increasing significantly since 2000 . There were a few (1-3) publications each year between 1920 and 1960. Then there was a small increase in the number of publications (7-10) per year in the late 1960s, which coincides with the beginning of the Athabasca acid oil sands refining in Canada [105]. The rapid increase in the number of publications (20-90) per year after 2000 accompanies improvements of analytical methods of detection of NA and use of opportunity acid crudes.

\section{Combined influence of $N A$ and sulfur compounds on corrosion of carbon steel}

Most oil refineries run alternately different kinds of crudes and crude blends. Usually high sulfur (sour) crudes have low acidity and opposite, low sulfur (sweet) crudes have high acidity. Probably Piehl R. L. [106] was the first who noted that iron sulfide scale had a protective role against $\mathrm{NAC}$, and competition between the sulfidic and NAC occurred.

Constant alternation of acid sweet crudes and low acid sour crudes in distillation units leads to complicated influence of corrosive components (sulfur compounds and organic acids, including naphthenic) in crudes on corrosion of carbon steel and low-alloy steels. NAC can be successfully inhibited on carbon steel and lowalloy steels by the moderate concentrations of $\mathrm{H}_{2} \mathrm{~S}$ in hydrocarbon media but can also be aggravated with higher $\mathrm{H}_{2} \mathrm{~S}$ concentrations. High concentrations of sulfur compounds increase high-temperature sulfur corrosion in hydrocarbon media. This situation is similar to passive region for dependence electric current - potential for some metals in definite electrolyte solution. Thus, the firmly established fact exists that $\mathrm{H}_{2} \mathrm{~S}$ can inhibit NAC at particular conditions depending on TAN, type of NA, temperature, flow rate, flow regime, and duration [107-110]. It is not simply to define this passive region (based on $\mathrm{H}_{2} \mathrm{~S}$ and NA concentrations) in real conditions at crude units because of many influenced factors. The case study described in [14] confirms such approach to the impact of the combined influence of sulfur content and acidity in crude oil and its fractions on their corrosiveness.

\section{Hydrogen damages}

Hydrogen damages can be divided into two groups based on two mechanisms: electrochemical processes (mainly at low temperature, up to $\sim 100^{\circ} \mathrm{C}$ ) arising from acid corrosion (including chemical cleaning and etching - "useful corrosion") and cathodic protection (when water molecules can be reduced to hydrogen atoms at certain negative electric potentials, less than $-1 \mathrm{~V}$ relative to copper/copper sulfate reference electrode), and high temperature (between 200 and $900^{\circ} \mathrm{C}$ ) arising from the presence of hydrogen gas at high pressures (4-30 MPa). It was suggested differentiating special case of appearing of hydrogen gas on carbon steel surface because of corrosion by organic acids (naphthenic acids among them) at $100-360^{\circ} \mathrm{C}[111,112]$.

Low-temperature hydrogen attack can occur in the overhead of atmospheric and vacuum distillation columns, amine treating, isomerization, fluid catalytic cracking, and alkylation units. Corrosion by organic acids (naphthenic acids among them) can occur in distillation units: rectification columns, piping, and heat exchangers.

The following preventive actions of hydrogen failures at low temperature exist $[2,114,115]$ :

a) Metallurgical measures: selection of materials resistant to hydrogen damages; use of steels containing chromium and molybdenum; use of HIC (HydrogenInduced Cracking) resistant or killed steels; decrease of carbon content in steel. Steels are not subjected to cracking at hardness values $\leq 22$ HRC (Hardness Rockwell).

b) Correct fabrication technique: optimal heat treatment and proper welding; to use induction heating stress improvement, dehydrogenation heat treatment, and PWHT (Post-Weld Heat Treatment); to lessen cold working. Preheating steel sheets to $100-150^{\circ} \mathrm{C}$ and decreasing cooling rate after welding can diminish this susceptibility.

c) Change of environmental conditions: removing sulfides, cyanides, and arsenic compounds; neutralization of acids; injection of inhibitors of acid corrosion and hydrogen penetration. 
d) Use of organic, inorganic, and metallic coatings.

High-temperature hydrogen attack (HTHA) takes place as a result of thermal dissociation of hydrogen molecules with the formation of hydrogen atoms, and their further penetration into metal or alloy. Hydrogen atoms can react with carbides (i.e. cementite $\mathrm{Fe}_{3} \mathrm{C}$ ) and carbon inside carbon steel forming methane gas (decarburization). As a result of this hydrogen damage, steel irreversibly loses mechanical properties, such as strength and toughness. HTHA can occur at hydrodesulfurizers, hydrocrackers, and catalytic reformer units.

Steels may be more resistant to hydrogen attack at high temperature by following actions:

a) Proper and careful choice of alloy and correct design are the most reliable method to prevent HTHA [115]. Austenitic stainless steels (300 series), as well as $12 \mathrm{Cr}, 9 \mathrm{Cr}$ and $5 \mathrm{Cr}$ are resistant to HTHA at conditions normally seen at oil refinery units.

b) Lowering the carbon content in the alloy and binding the remaining carbon into stable, dispersed carbides (addition of $\mathrm{Cr}, \mathrm{Mo}$, and $\mathrm{V}$ ).

c) Compliance with technological regime: strictly control designing processing parameters (temperature and pressure).

In spite of existing of different methods of hydrogen monitoring, there is no reliable method allowable predicting where and when hydrogen damage will happen.

\section{Corrosion by amine solutions}

Aqueous amine solutions have been used since 1930 s to remove acid gas contaminants $\left(\mathrm{H}_{2} \mathrm{~S}\right.$ and $\left.\mathrm{CO}_{2}\right)$ by absorption from a process stream [116]. Following four amines are used: monoethanolamine (MEA), diethanolamine (DEA), methyldiethanolamine (MDEA), and diisopropanol amine (DIPA). Corrosion problems at amine treating units usually happen because of faulty plant design, poor operating practices, and amine solution contamination [93]. The four amines themselves are not corrosive to carbon steel, even can play the role of corrosion inhibitors under certain conditions. However, they can degrade during long circulation at high temperature (if steam temperature exceeds $150^{\circ} \mathrm{C}$ ), and destructed products of amines together with $\mathrm{H}_{2} \mathrm{~S}$ and other contaminants can cause corrosion problems.

Corrosion in amine treating units depends on amine type, acid gas removal service and molar ratio $\mathrm{H}_{2} \mathrm{~S} /$ amine (called also loading), and type and concentration of amine degradation products [113, 117]. Corrosion in amine units using MEA is more severe than in those using DEA, MDEA, and DIPA, because the former is more prone to degradation. MDEA is considered to cause the less corrosion problems compared to MEA, DEA and
DIPA. In addition to $\mathrm{H}_{2} \mathrm{~S}$, such contaminants as formic acid, acetic acid, glycolic acid, propionic acid, oxalic acid, chlorides, sulfates, thiosulfate, and thiocyanate can be present or produced by oxidation of hydrocarbons in the amine solution. These contaminants react with amine producing salts formate, acetate, glycolate, propionate, oxalate, and also chloride, sulfate, thiosulfate, and thiocyanate. They got the name heat stable amine salts (HSAS) or simply heat stable salts (HSS) because it is impossible to destroy them under normal regenerator conditions, namely, they cannot be recovered by heating. As a result, HSAS are accumulated in the amine solution which becomes more and more corrosive with time. The presence of HSAS also diminish the efficiency of the absorbing ability of amine solution by reducing the amount of pure amine. Therefore, maximum allowable concentration is $1 \mathrm{wt} \%$ HSAS in amine solution. When its quantity more than this value, unfavorable HSAS accumulating in amine solution give rise to severe corrosion, erosion, precipitation of solids, causing fouling and under deposit corrosion. Corrosion is most harsh at locations where $\mathrm{H}_{2} \mathrm{~S}$ is removed from rich (by $\mathrm{H}_{2} \mathrm{~S}$ ) amine solution, namely, in reboilers. Really, temperatures, appearance of two-phase turbulence stream and flow velocity are the highest in these locations. Corrosion can be a problem on the rich-amine side of the heat exchangers, in reclaimers, and pumps. Hydrogen damages (blistering because of $\mathrm{H}_{2} \mathrm{~S}$ presence) can occur in the bottom of the absorber, overhead condensers, and reflux drums. Aqueous amine solutions can cause SCC of carbon steel welds, therefore, PWHT at $620^{\circ} \mathrm{C}$ should be applied. The following solutions to lessen and prevent these detrimental corrosion-erosion and fouling problems exist:

a) Correct molar ratio $\mathrm{H}_{2} \mathrm{~S} /$ amine. Operating practice requires to maintain the following parameters in amine treating units: MEA concentration should not exceed $20 \mathrm{wt} \%$; acid-gas loading should be $0.35 \mathrm{~mol}$ $\mathrm{H}_{2} \mathrm{~S} /$ mol MEA and 0.05 mole $\mathrm{H}_{2} \mathrm{~S} /$ mole MDEA; and reboiler steam temperature less than $150^{\circ} \mathrm{C}$.

b) Neutralization with proprietary neutralizers.

c) Clean-up the amine solution: change out, purge and make up fresh amine solution, vacuum thermal distillation, ion exchange, and electrodialysis [113, $114,118]$.

d) It is recommended to replace carbon steel with $\mathrm{SS}$ 304 if corrosion problems cannot be solved by improving operating conditions and purification of amine solution.

\section{Petrochemical plant}

Petrochemical plant consists of units resembling those at oil refinery. And even many media and environment are similar. Raw original organic material 
comes from refinery. Reformate producing at the $\mathrm{CCR}$ (Continuous Catalytic Regeneration Reforming) and FCC (Fluid Catalytic Cracking) units is fed to petrochemical plant to produce aromatics. These specific organic solvents can dissolve water and oxygen [32, 119, 120]. For instance, the solubility of oxygen in benzene is $70 \mathrm{ppm}$ and in water is $8.5 \mathrm{ppm}$ at $25^{\circ} \mathrm{C}$ [42]. Moreover, if the solubility of oxygen in water is decreased with increasing temperature, that in benzene is increased. Chlorides also can be main corrosive contaminant in reformate coming from the oil refinery. Sulfolane widely used for extraction aromatics can degrade into acidic corrosive products. Specific corrosion case study is analyzed in [14].

\section{Corrosion management}

Corrosion (if not managed, namely, controlled or prevented) can result in catastrophes. Therefore, oil and gas production, refineries and petrochemical plants should manage their units safely. For this, they have to make efforts to control technological processes and organize corrosion management strategies in order to diminish corrosion accident risks to a minimum.

Corrosion management includes planning actions for determination of corrosion risk, performance requirements of standards, recommended practices and specifications for correct selection of materials, corrosion protection, and monitoring methods. This should be carried out at the stage of design and then their realization in practice under inspection, control, and monitoring. Study of each accident with failure analysis, coordination, education, and knowledge transfer are also necessary components of corrosion management methodology.

Thus, corrosion management is a wide spectrum of measures and procedures of interaction between different services and specialties, from a worker to a head, from an engineer to a purchaser and a lawyer.

Corrosion management program does not necessarily require establishing a "zero corrosion rate" system, but rather establishing operating limits, monitoring and inspection plans to assure acceptable corrosion rates which allow the system to function reliably and safely.

The human factor is a key issue in corrosion management and diminishing corrosion accidents. The causes of humans' mistakes are the lack of awareness, education, knowledge and training, incorrect design, insufficient control and supervision, lack of motivation and incentives to decrease the corrosion risk, wrong operation, and element of change.

Improving corrosion management we reduce the corrosion risk in oil, gas and refining industry and its negative influence on the environment and society. It is suggested to establish legislation about corrosion management on the state level (like legislation about pollutions and environmental protection), to improve education and knowledge transfer [121]. Penalties of management can force them to put more attention on corrosion problems and make it priority issue at oil, gas and refinery plants.

It is needed to work out corrosion management programs with planned investments at each stage of design, fabrication, implementation of anti-corrosion measures, operation, monitoring, inspection, maintenance, education, knowledge transfer, training, and research.

\section{REFERENCES}

1. A. J. Kidnay, W. R. Parrish, D. G. McCartney, Fundamentals of Natural Gas Processing, Second Edition, CRC Press Taylor \& Francis Group, Boca Raton, FL, USA, 2011, 552 p.

2. NACE MR0175/ISO15156, Petroleum and natural gas industries - Materials for use in $\mathrm{H}_{2} \mathrm{~S}$-conatining environments in oil and gas production, NACE International, Houston, TX, 2015, 164 p.

3. D. E. Milliams and R.N. Tuttle. ISO 15156/NACE MR0175 - A new international standard for metallic materials for use in oil and gas production in sour environments. Paper no. 03090, NACE CORROSION 2003 Conference, NACE International, Houston, TX, USA, 2003, 10 p.

4. NORSOK M-001, Materials Selection, 5th Edition, 2014, $32 \mathrm{p}$.

5. Heidersbach R (2011) Metallurgy and Corrosion Control on Oil and Gas Production. John Wiley \& Sons, Inc, Hoboken, New Jersey, USA.

6. M.W. Joosten, J. Kost, J. Hembree, and M. Achour Organic Acid Corrosion in Oil and Gas Production. Paper no. 02294, NACE CORROSION 2002 Conference, NACE International, Houston, TX, USA, 2002, 13 p.

7. T.R. Andersen, A.M.K. Halvorsen, A Valle, G.P. Kojen, and A. Dugstad. The Influence of Condensation Rate and Acetic Acid Concentration on TOL-Corrosion in Multiphase Pipelines. Paper no. 07312, NACE CORROSION 2007 Conference, NACE International, Houston, TX, USA, 2007, 14 p.

8. K. George, S. Nešić, and C. de Waard, Electrochemical Investigation and Modeling of $\mathrm{CO}_{2}$ Corrosion of Mild Steel in the Presence of Acetic Acid, Paper no. 04379, CORROSION 2004, NACE International, Houston, TX, USA, 2004, 25 p.

9. Agency for Toxic Substances and Disease Registry (ATSDR), Toxicological profile for mercury. Atlanta, GA: U.S. Department of Health and Human Services, Public Health Service, 1994.

10. J.M. Campbell, Gas Conditioning and Processing, Vol.1: The Basic Principles, 8th ed., Ed. M. John, 2004, Campbell and Company.

11. B. Traconis, Y.D. Mierez, and A. Jimenez. Mercury removal systems at Santa Barbara Extraction Plant. In: Proceedings of the $75^{\text {th }}$ Annual Convention Gas Processors Association, Tulsa, OK, USA, 1996, p. 123. 
12. N. Eckersley, Advanced mercury removal technologies. Hydrocarbon Processing, 2010, 69(1): 29-35.

13. J. Stiltner, Mercury removal from natural gas and liquid streams. In: Proceeding of the $81^{\text {st }}$ Annual Convention Gas Processors Association, Tulsa, OK, USA, 2002.

14. Alec Groysman, Corrosion Problems and Solution in Oil Refining and Petrochemical Industry. Springer, Dordrecht, $2016,356 \mathrm{p}$

15. S. Nešić, Key issues related to modelling of internal corrosion of oil and gas pipelines - A review, Corrosion Science, 2007, Vol. 49, pp. 4308-4338.

16. F. Vitse, S. Nešić, Y. Gunaltun, D. Larrey de Torreben, and P. Duchet-Suchaux, Mechanistic Model for the Prediction of Top-of-the-Line Corrosion Risk, Corrosion, 2003, 59(12):1075-1084.

17. M. Estavoyer, Corrosion Problems at Lacq Sour Gas Field, In: $\mathrm{H}_{2} \mathrm{~S}$ Corrosion in Oil and Gas Production, NACE, Houston, TX, USA, 1981, p. 905.

18. R. Pailassa, M. Dieumegarde, and M. Estavoyer, Corrosion Control in the Gathering System at Lacq Sour Gas Field, In: $\mathrm{H}_{2} \mathrm{~S}$ Corrosion in Oil and Gas Production, NACE, Houston, TX, USA, 1981, p. 860.

19. R. Nyborg and A. Dugstad. Top of Line Corrosion and Water Condensation Rates in Wet Gas Pipelines. Paper no. 07555, NACE CORROSION 2007 Conference, NACE International, Houston, TX, USA, 2007, $10 \mathrm{p}$.

20. Y.M. Gunaltun, D. Larrey, Correlation of Cases of Top of Line Corrosion With Calculated Water Condensation Rates, Paper no. 00071, CORROSION 2000, NACE International, Houston, TX, USA, 2000, 15 p.

21. Top-of-Line Corrosion Conclusion: Models updated; remediation strategies set out, Oil \& Gas Journal, 2000, July 10, p. 58 .

22. Y. M. Gunaltun, Combining Research and Field Data for Corrosion Rate Prediction, Paper no. 27, Corrosion/96 Conference, NACE, Houston, TX, USA, 1996, 16 p.

23. F. Vitse et al., Semi-empirical model for prediction of the Top-Of-the-Line corrosion risk, Paper no. 02245, NACE CORROSION 2002 Conference, NACE International, Houston, TX, USA, 2002, 17 p.

24. Z. Zhang, D. Hinkson, M. Singer, H. Wang, and S. Nesic, A Mechanistic Model of Top of the Line Corrosion, Paper no. 07556, NACE CORROSION 2007 Conference, NACE International, Houston, TX, USA, 2007, 22 p.

25. I. Jevremović, M. Singer, M. Achour, V. MiškovićStanković and S. Nešić. Evaluation of a Novel Top-ofthe-Line Corrosion (TLC) Mitigation Method in a LargeScale Flow Loop. Corrosion, 2015, 71(3):389-397.

26. M. Singer, D. Hinkson, Z. Zhang, H. Wang, and S. Nešić. $\mathrm{CO}_{2}$ Top-of-the-Line Corrosion in Presence of Acetic Acid: A Parametric Study. Corrosion, 2013, 69 (7): 719-735.

27. I. Jevremović, et al., A Novel Method to Mitigate the Top-of-the-Line Corrosion in Wet Gas Pipelines by Corrosion Inhibitor within a Foam Matrix. Corrosion, 2013, 69(2):186-192.

28. Y. M. Gunaltun, D. Supriyatman, and J. Achmad, Topof-Line corrosion in gas lines confirmed by condensation analysis, Oil \& Gas Journal, 1999, 97(28).

29. Ming Shen, Alla Furman, Rita Kharshan, and Tim Whited, Development of Corrosion Inhibitors for Prevention of
Top of the Line Corrosion (TLC), Paper no. 2509, NACE CORROSION 2013 Conference, NACE International, Houston, TX, USA, 2013, 12 p.

30. Z. Belarbi, F. Farelas, M. Singer, and S. Nesic, Role of Amine in the Mitigation of $\mathrm{CO}_{2}$ Top of the Line Corrosion. Paper no. 7274, NACE CORROSION 2016 Conference, NACE International, Houston, TX, USA, 2016, 15 p.

31. Standard Handbook of Petroleum and Natural Gas Engineering, Eds. WC. Lyons, G.J. Plisga, and M. Lorenz, Third Edition, Gulf Professional Publishing, USA, 2015, $1822 \mathrm{p}$.

32. Alec Groysman, Corrosion for Everybody. SpringerVerlag, Dordrecht, 2010, 368 p.

33. S. Nešić, G.T. Solvi, and J. Enerhaug, Comparison of the Rotating Cylinder and Pipe Flow Tests for Flow-Sensitive Carbon Dioxide Corrosion, Corrosion, 1995, 51(10): 773-787.

34. E.D. Sloan, C. Koh, Clathrate Hydrates of Natural Gases, Third Edition, CRC Press, Taylor \& Francis Group, USA, 2007, $752 \mathrm{p}$.

35. S. Guo, F. Farelas, and M. Singer, Effect of monoethylene glycol on sweet top of the line corrosion. Paper no. 7891, NACE CORROSION 2016 Conference, NACE International, Houston, TX, USA, 2016, 17 p.

36. Study on oil refining and oil markets, Prepared for European Commission by Purvin \& Gertz Inc., 2008, 377 p. http://ec.europa.eu/dgs/energy transport/security/studies/ doc/energy/2008_01_study_oil_refining_oil_markets_ en.pdf

37. Use of Corrosion-Resistant Alloys in Oilfield Environments. NACE International Publication 1F192 (2013 Edition), USA, $61 \mathrm{p}$.

38. Bruce D. Craig, Selection guidelines for corrosion resistant alloys in the oil gas industry, Technical Publication No. 10073, The Nickel Development Institute, 1995, 11p. http://www.stainless-steel-world.net/pdf/10073.pdf

39. R.D. Kane, B. Craig, A. Venkatesh. Titanium Alloys for Oil and Gas Service: A Review. Paper no. 09078, NACE CORROSION 2009 Conference, NACE International, Houston, TX, 2009, 21 p.

40. L.W. McKeen, R. Albert, and J. Hofmans, Corrosion Testing of Fluorocoatings for Oil/Gas Production Tubing, Paper no. 08029, NACE CORROSION 2008 Conference, NACE International, Houston, TX, USA, 2008, 9 p.

41. C.J. Kau, Luc Vanderschuren, and C.A. Veith, Polyketone Polymers: A New Liner Material for Corrosion Control in Oil and Gas Industry, Paper no. 00787, NACE CORROSION 2000 Conference, NACE International, Houston, TX, USA, 2000, 16 p.

42. Groysman A (2014) Corrosion in Systems for Transportation and Storage of Petroleum Products and Biofuels. Springer, Dordrecht, $297 \mathrm{p}$.

43. NACE Standard Practice SP0169-2013, Control of External Corrosion on Underground or Submerged Metallic Piping Systems. NACE International, Houston, TX, USA, 2013, $60 \mathrm{p}$.

44. NORSOK Standard M-CR-503, Cathodic protection, Edition 3, 2007, 15 p.

45. NACE SP0176-2007, Corrosion Control of Submerged Areas of Permanently Installed Steel Offshore Structures Associated with Petroleum Production, NACE International, Houston, TX, USA, 2007, 33 p. 
46. NACE Standard RP0193-2001, External Cathodic Protection of On-Grade Carbon Steel Storage Tank Bottoms, NACE International, Houston, TX, USA, 2001, 23 p.

47. NACE International Publication 10A392, Effectiveness of Cathodic Protection on Thermally Insulated Underground Metallic Structures, NACE International, Houston, TX, USA, 2006, 8 p.

48. NACE Standard SP0285-2011, External Corrosion Control of Underground Storage Tank Systems by Cathodic Protection, NACE International, Houston, TX, USA, 2011, 23 p.

49. NACE Standard SP0286-2007, Electrical Isolation of Cathodically Protected Pipelines, NACE International, Houston, TX, USA, 2007, $20 \mathrm{p}$.

50. NACE Standard Test Method TM0101-2012, Measurement Techniques Related to Criteria for Cathodic Protection of Underground Storage Tank Systems, NACE International, Houston, TX, USA, 2012, 34 p.

51. R. J. Kuhn, Cathodic Protection of Underground Pipe Lines from Soil Corrosion, API Proceedings, November 1933, Vol. 14, p. 157.

52. R. J. Kuhn, Cathodic Protection on Texas Gas Systems, AGA, April 1950.

53. R.A. (Bob) Gummow, Examining the Controversy Surrounding the $-850 \mathrm{mV}$ CP Criteria, Pipeline \& Gas Journal, 2010, 237(11).

54. A.C. Toncre, The Relationship of Coatings and Cathodic Protection for Underground Corrosion Control, In: ASTM STP 741, Ed. E. Escalante, ASTM, USA, 1981, pp. 166181.

55. M. Foss, E. Gulbrandsen, and J. Sjoblom, Effect of Corrosion Inhibitors and Oil on Carbon Dioxide Corrosion and Wetting of Carbon Steel with Ferrous Carbonate, Corrosion, 2009, 65(1): 3-14.

56. S. A. Bradford, Corrosion Inhibitors, In: Corrosion Control, $2^{\text {nd }}$ edition, ASM International, 2002, pp. 345371.

57. Paul J. Stone, Corrosion Inhibitors for Oil and Gas Production. In: Corrosion, Vol. 13, Ninth Edition, ASM International, USA, 1987, pp. 478-486.

58. J. Cai, S. Nešić, C. de Waard, Modeling of Water Wetting in Oil-Water Pipe Flow, Paper no. 04663, CORROSION 2004, NACE International, Houston, TX, USA, 2004, 19 p.

59. S. E. Hernandez, J. Bruzual, F. Lopez-Linares, J. G. Luzon, Isolation of Potential Corrosion Inhibiting Compounds in Crude Oils, Paper no. 03330, CORROSION 2003, Houston, TX, USA, NACE International, 2003, 24 p.

60. S. E. Hernandez, S. Duplat, J. R. Vera, E. Baron, A Statistical Approach for Analyzing the Inhibiting Effect of Different Types of Crude Oil in $\mathrm{CO}_{2}$ Corrosion of Carbon Steel, CORROSION 2002, paper no. 02293, Houston, TX, USA, NACE International, 2002, $17 \mathrm{p}$.

61. C. Mendez, S. Duplat, S. Hernandez, J. Vera, On the Mechanism of Corrosion Inhibition by Crude Oils, Paper no. 01044, CORROSION 2001, Houston, TX, USA, NACE International, 2001, $19 \mathrm{p}$.

62. B.M. Miksic, A.Y. Furman, M.A. Kharshan, Effectiveness of the Corrosion Inhibitors for the Petroleum Industry Under Various Flow Conditions, Paper no. 09573, CORROSION 2009, NACE International, Houston, TX, USA, 2009, 9 p.
63. I. Jevremović, M. Singer, S. Nešić, and V. MiškovićStanković. Electrochemistry of carbon dioxide corrosion mitigation using tall oil diethylenetriamine imidazoline as corrosion inhibitor for mild steel. Materials and Corrosion, 2016, 67(7):756-768.

64. V.S. Sastri, Green Corrosion Inhibitors, John Wiley \& Sons, Inc., Hoboken, New Jersey, USA, 2011, 310 p.

65. ASTM G170-01a, Standard Guide for Evaluation and Qualifying Oilfield and Refinery Corrosion Inhibitors in the Laboratory, ASTM International, 2001, 17 p.

66. NACE International Publication 1D182, Wheel Test Method Use for Evaluation of Film-Persistent Corrosion Inhibitors for Oilfield applications, NACE International, Houston, TX, USA, 2005, 4 p.

67. S. Papavinasam, W.R. Revie, M. Attard, A. Demoz, and K. Michaelian, Comparison of Laboratory Methodologies to Evaluate Corrosion Inhibitors for Oil and Gas Pipelines, Corrosion, 2009, 59(10): 897-912.

68. T.H. Bieri, D. Horsup, M. Reading, and R.C. Woolam, Corrosion Inhibitor Screening Using Rapid Response Corrosion Monitoring, Paper no. 06692, CORROSION 2006, NACE International, Houston, TX, USA, 2006, 16 p.

69. NACE SP0775-2013, Preparation, Installation, Analysis, and Interpretation of Corrosion Coupons in Oilfield Operations, NACE International, Houston, TX, USA, 2013, 24 p.

70. D.E. Powell, Methodology for Designing Field Tests to Evaluate Different Types of Corrosion in Crude Oil Production Systems, Paper no. 04367, CORROSION 2004, NACE International, Houston, TX, USA, 2004, 17 p.

71. Techniques for Monitoring Corrosion and Related Parameters in Field Applications, NACE International Publication 3T199 (2012 Edition), 69 p.

72. A. Groysman, Corrosion Monitoring, Corr. Rev., 2009, Vol. 27, Nos. 4-5, pp. 205-343.

73. NACE Standard RP0497-2004, Field Corrosion Evaluation Using Metallic Test Specimens, NACE International, USA, 2004, $26 \mathrm{p}$.

74. ASTM G4-01(2014). Standard Guide for Conducting Corrosion Tests in Field Applications, ASTM International, USA, 2014, $10 \mathrm{p}$.

75. ASTM G31-72(2004), Standard Practice for Laboratory Immersion Corrosion Testing of Metals, ASTM International, USA, 2004, 8 p.

76. ASTM G1-03(2011), Standard Practice for Preparing, Cleaning and Evaluating Corrosion Test Specimens, ASTM International, USA, 2011, 9 p.

77. A. Abdulhadi et al., Field and Laboratory Experiences with Advanced Electrical Resistance Online Corrosion Monitoring System, Paper no. 07265, CORROSION 2007, NACE International, Houston, TX, USA, 2007, 10 p.

78. ASTM G96-90(2013), Standard Guide for Online Monitoring of Corrosion in Plant (Electrical and Electrochemical Methods). ASTM International, USA, 2013, $10 \mathrm{p}$.

79. W.R. Haag and C.Wrenn, The PID Handbook - Theory and Applications of Direct-Reading Photoionization Detectors (PIDs), 2nd. Ed., San Jose, CA: RAE Systems Inc., 2006.

80. J.E. Nyquist, D.L. Wilson, L.A. Norman, and R.B. Gammage, Decreased sensitivity of photoionization detector total organic vapor detectors in the presence of methane. Am. Ind. Hyg. Assoc. J., 1990, 51, pp. 326-330. 
81. NACE SP0208-2008. Internal Corrosion Direct Assessment Methodology for Liquid Petroleum Pipelines, NACE International, USA, 2008, $35 \mathrm{p}$.

82. NACE Standard TM0109-2009, Aboveground Survey Techniques for the Evaluation of Underground Pipeline Coating Condition, NACE International, USA, 2009, 35 p.

83. NACE Standard SP0502-2010, Pipeline External Corrosion Direct Assessment Methodology, NACE International, USA, 2010, $57 \mathrm{p}$.

84. NACE Standard SP0207-2007, Standard Practice Performing Close-Interval Potential Surveys and DC Surface Potential Gradient Surveys on Buried or Submerged Metallic Pipelines, NACE International, USA, 2007, $51 \mathrm{p}$.

85. S.M. Segall, R.G. Reid, R.A. Gummow, Use of an Integrated CIPS/DCVG Survey in the ECDA Process, Paper No. 06193, CORROSION 2006, NACE International, USA, 2006, $12 \mathrm{p}$.

86. S.M. Segall, R.A. Gummow, John Shore, and R.G. Reid, Ensuring the Accuracy of Indirect Inspections Data in the ECDA Process, Paper No. 10061, CORROSION 2010, NACE International, USA, 2010, 13 p.

87. Arturo Godoy et al., Numerical Modeling of Cathodic Protection System Looking for Present Condition Evaluation and Improvement of Pipeline Network at Manzanillo, Mexico, Paper No. 10068, CORROSION 2010, NACE International, USA, 2010, 8 p.

88. K.R. Larsen, Proposed Changes to Gas Transmission Pipeline Regulations Intended to Increase Safety, Materials Performance, 2016, 55(12), pp. 16-19.

89. Department of Transportation, Pipeline and Hazardous Materials Safety Administration, "Pipeline Safety: Safety of Gas Transmission and Gathering Pipelines; Proposed Rule," Federal Register, 2016, 81, 69, pp. 20,722-20,856.

90. U.S. Code of Federal Regulations (CFR) Title 49, Part 192, "Transportation of Natural and Other Gas by Pipeline: Minimum Federal Safety Standards", Washington, DC: Office of Federal Register, 2016.

91. Final Investigation Report "Chevron Richmond Refinery: Pipe Rupture and Fire", U.S. Chemical Safety and Hazard Investigation Board, Report No. 2012-03-I-CA, January 2015, $132 \mathrm{p}$.

92. Groysman A, Kaufman A, Feldman B, Balali R, Hydrogen Damage and Prevention in the Oil Refinery, Paper No. 11295, NACE International 2011 Conference, 13-17 March 2011, 15 p.

93. Gutzeit J, Merrick RD, Scharfstein LR (1987) Corrosion in Petroleum Refining and Petrochemical Operations. In: Corrosion, Vol. 13, ASM Handbook, ASM International, USA, pp. 1262-1287.

94. White RA, Ehmke EF (1991) Materials Selection for Refineries and Associated Facilities NACE, USA, p. 65.

95. Gutzeit J (2006) Crude Unit Corrosion Guide. PCC Process Corrosion Consultants, USA.

96. NACE International Publication 43104 (2014) Overview of Sulfidation (Sulfidic) Corrosion in Petroleum Refining Hydroprocessing Units. NACE International, Houston, TX, USA.

97. API RP 939-C (2008) Guidelines for Avoiding Sulfidation (Sulfidic) Corrosion Failures in Oil Refineries. American Petroleum Institute, Washington D.C., USA.
98. Catalytic Naphtha Reforming (2004) Antos GJ, Aitani AM (eds), Second edition, Marcel Dekker, Inc., New York, USA.

99. Wiehe IA (2008) Process Chemistry of Macromolecules. CRC Press Taylor \& Francis Group, Boca Raton, FL, USA.

100. Wang W, Watkinson AP (2011) Iron sulfide and coke fouling from sour oils: review and initial experiments. In: Proceedings of International Conference on Heat Exchanger Fouling and Cleaning, June 05-10 2011, Crete Island, Greece, pp. 23-30.

101. Shah P et al (2015) Advances in processing high naphthenic acid crudes. PTQ Q2 2015, 1-7. www. digitalrefining. com/article/1001119.

102. Johnson D, MacAteer G, Zuk H (2002) Naphthenic Acid Corrosion Field Evaluation and Mitigation Studies. ERTC (European Refining Technology Conference), $7^{\text {th }}$ Annual Meeting, Paris, France.

103. Jayaraman A, Singh H, Lefebvre Y (1986) Naphthenic Acid Corrosion in Petroleum Refineries. A Review. Revue de 1'Institute Francais Du Pétrole 41(2):265-274.

104. Speight JG (2014) High Acid Crudes. Elsevier Inc., Oxford.

105. Grewer DM, Young RF, Whittal RM, Fedorak PM (2010) Naphthenic acids and other acid-extractables in water samples from Alberta: What is being measured? Science of the Total Environment 408:5997-6010.

106. Piehl RL (1988) Naphthenic acid corrosion in crude distillation units. Mater. Perform. 27(1):37-43.

107. Kane RD, Chambers B (2011) High Temperature Crude Oil Corrosivity: Where Sulfur and Naphthenic Acid Chemistry and Metallurgy Meet. Paper 4A presented at the Corrosion Solutions Conference 2011 Proceedings, pp. 137-144.

108. Kane RD, Cayard MS (2002) A Comprehensive Study on Naphthenic Acid Corrosion. Paper No. 02555, NACE CORROSION 2002 conference, NACE International, Houston, TX, USA.

109. Kane R, Trillo E (2006) The State-of-the-Art of Naphthenic Acid and Sulfidic Corrosion Evaluation and Prediction. Presentation at the 2006 Spring Meeting \& $2^{\text {nd }}$ Global Congress on Process Safety, 9 $^{\text {th }}$ Topical Conference on Refinery Processing, AIChE, USA.

110. Bota GM et al (2010) Naphthenic Acid Corrosion of Mild Steel in the Presence of Sulfide Scales Formed in Crude Oil Fractions at High Temperature. Paper No. 10353, NACE CORROSION 2010 conference, NACE International, Houston, TX, USA.

111. Groysman A et al (2007) Naphthenic Acid Corrosion Study. In: Procedd. EUROCORR conference, 9-13 September 2007, Freiburg im Breisgau, Germany.

112. Groysman A et al (2007) Low Temperature Naphthenic Acid Corrosion Study. Paper No. 07569, NACE CORROSION 2007 conference, NACE International, Houston, TX, USA.

113. Liu HJ, Dean JW, Bosen SF (1995) Neutralization Technology to Reduce Corrosion from Heat Stable Amine Salts. Paper No. 572, NACE conference Corrosion/95, NACE International, Houston, TX, USA.

114. Gregory RA, Cohen MF (1988) Removal of salts from aqueous alkanolamine using an electrodialysis cell with ion exchange membrane. European Patent 286,143. 
115. API RP 941 (2008) Steels for Hydrogen Service at Elevated Temperatures and Pressures in Petroleum Refineries and Petrochemical Plants. Seventh Edition, American Petroleum Institute, Washington, D.C., USA.

116. Bottoms RR (1930) Process for separating acidic gases. US Patent 1,783,901.

117. DuPart MS, Bacon TR, Edwards DJ (1993) Understanding corrosion in alkanolamine gas treating plants. Hydrocarbon Processing. Part 1, 72(4):75-79. Part 2, 72(5):89-94.

118. Burns D, Gregory RA (1995) The UCARSEPTM Process for On-Line Removal of Non-Regenerable Salts form Amine Units. Paper presented at the Laurance Reid Gas
Conditioning Conference, The University of Oklahoma, Norman, OK, USA.

119. Groysman A, Erdman N (2000) A Study of Corrosion of Mild Steel in Mixtures of Petroleum Distillates and Electrolytes. Corrosion 56(12):1266-1271.

120. Groysman A (2005) Corrosion of Aboveground Fuel Storage Tanks. Mater. Perform. 44(9):44-48.

121. A. Groysman, The Role of Corrosion Management in Prevention of Corrosion Failures, Paper No. 7252, NACE International 2016 Conference, 6-10 March 2016, Vancouver, Canada, $15 \mathrm{p}$. 